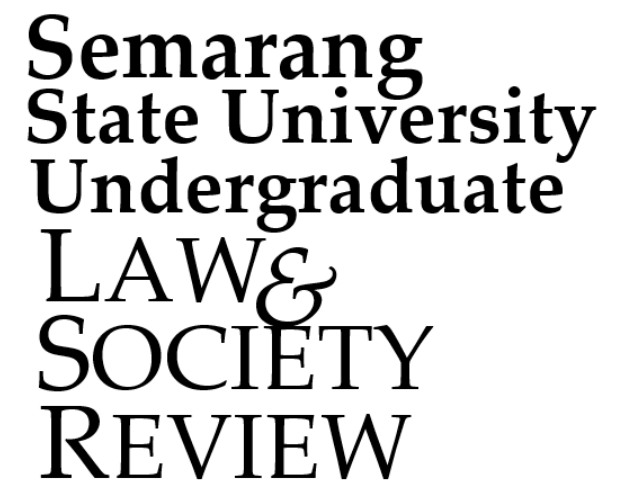

VOLUME 1 ISSUE 1, JANUARY 2021
ISSN (Print): 2807-8225 ISSN (Online): 2807-8683

\section{History of Article}

Submitted: November 2020

Revised: December 2020

Accepted: January 2021

How to cite:

Ambarrini, B. K. (2021). Review of Sherlock Holmes The Complete Novels and Stories. Semarang State University Undergraduate Law and Society Review, 1(1), 87-94. https://doi.org/10.15294/lsr.v1i1.50112

(C) 2021 Authors. This work is licensed under a AttributionNonCommercial-ShareAlike 4.0 International (CC BY-NC-SA 4.0). All writings published in this journal are personal views of the authors and do not represent the views of this journal and the author's affiliated institutions.

\title{
Review of Sherlock Holmes The Complete Novels and Stories
}

\author{
Benedicta Keisya AMBARRINI® \\ Universitas Negeri Semarang \\ Jl. Kampus Timur, Sekaran, Gunungpati, Semarang, INDONESIA \\ 凶benedictakeisya@students.unnes.ac.id
}

\begin{abstract}
The Sherlock Holmes stories were the source of modern crime-solving adaptations that we now experience in television, and Doyle's tales of mystery and adventure were often audacious, insightful and clever. The real draw of his stories is the process of crime detection, that Doyle allows the readers to understand, experience and apply themselves alongside Watson as Holmes investigates the cases.
\end{abstract}

KEYWORDS. Book Review, Sherlock Holmes, The Complete Novels and Stories 


\section{IDENTITY OF THE BOOK}

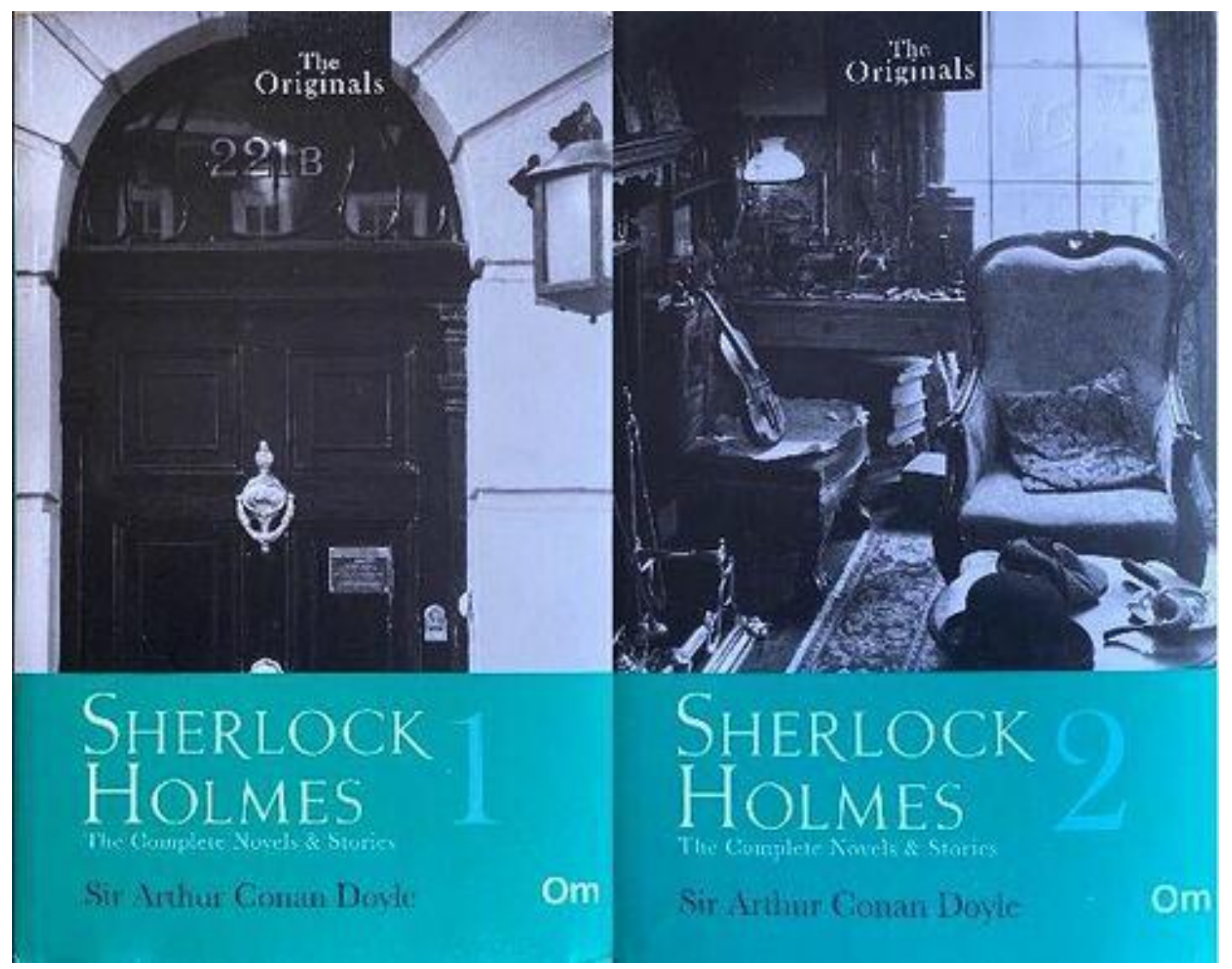

Title of Book

: Sherlock Holmes: The Complete Novels and Stories

Year of Publication

: 1986

Publisher

: Bantam Dell a Division of Random House

City of Publisher

: New York

Total of Pages

: 1059 Pages

ISBN

: 0-553-21241-9 


\section{GENERAL OVERVIEW OF THE BOOK}

Since his first appearance in Beeton's Christmas Annual in 1887, Sir Arthur Conan Doyle's Sherlock Holmes has been one of the most beloved fictional characters ever created. Until right now, in two paperback volumes, Bantam presents all fifty-six short stories and four novels featuring Conan Doyle's classic hero a truly complete collection of Sherlock Holmes's adventures in crime.

Volume I include the early novel A Study in Scarlet, which introduced the eccentric genius of Sherlock Holmes to the world. This baffling murder mystery, with the cryptic word Rache written in blood, first brought Holmes together with Dr. John Watson. Next, The Sign of Four presents Holmes's famous "seven percent solution" and the strange puzzle of Mary Morstan in the quintessential locked room mystery. Also included are Holmes's feats of extraordinary detection in such famous cases as the chilling "The Adventure of the Speckled Band," the baffling riddle of "The Musgrave Ritual," and the ingeniously plotted "The Five Orange Pips," tales that bring to life a Victorian England of horse-drawn cabs, fogs, and the famous lodgings at 221B Baker Street, where Sherlock Holmes earned his undisputed reputation as the greatest fictional detective of all time.

A study in scarlet. The sign of four. Adventures of Sherlock Holmes, A scandal in Bohemia, The red-headed league, A case of identity, The Boscombe Valley mystery, The five orange pips, The man with the twisted lip, The adventure of the blue carbuncle, The adventure of the speckled band, The adventure of the engineer's thumb, The adventure of the noble bachelor, The adventure of the beryl coronet, The adventure of the copper beeches, Memoirs of Sherlock Holmes, Silver blaze, The yellow face, The stock-broker's clerk, The "Gloria Scott", The musgrave ritual, The Reigate puzzle, The crooked man, The resident patient, The Greek interpreter, The naval treaty, The final problem, The return of Sherlock Holmes, The adventure of the empty house, The adventure of the Norwood builder, The 
adventure of the dancing men, The adventure of the solitary cyclist, The adventure of the priory school, The adventure of Black Peter, The adventure of Charles Augustus Milverton, The adventure of the six Napoleons, The adventure of the three students, The adventure of the golden pince-nez, The adventure of the missing three-quarter, The adventure of the abbey grange, The adventure of the second stain.

Anyway, the critic about this book is, overall, this novel was good, but the language structure and the grammatical was so hard to understand because this book was originally release in 1887 and it's kind of too old for readers in this era.

\section{LEGAL ISSUES ON THE BOOK}

The Sherlock Holmes stories were the source of modern crime-solving adaptations that we now experience in television, and Doyle's tales of mystery and adventure were often audacious, insightful, and clever. The real draw of his stories is the process of crime detection, that Doyle allows the readers to understand, experience and apply themselves alongside Watson as Holmes investigates the cases.

The Complete Sherlock Holmes volumes 1 and 2 by Bantam publishing co. had never changed. They're affordable and therefore anyone who is interested in the Great Detective will have an easy access. With the modern adaptations of Holmes lately a new reader may be surprised to find out that Doyle's stories are more self-contained as opposed to the James-Bond tone and setting of the modern interpretations mentioned in fact, the American adaptation Elementary is a lot more faithful to the original structure of the narrative. Nevertheless, the Doyle canon composed of 56 short stories classified into the Adventures, Memoirs, Return, His Last Bow and Casebook and four novels are more engrossing and intimate to read as Watson's accounts manages to illuminate Holmes' methods as well as humanize the often callous, razor-sharp, and unfeeling sleuth. 
Volume 1 encompasses The Adventures, The Memoirs and the novels A Study in Scarlet and The Sign of Four. A Scarlet in Scarlet has an unusual structure, the first part was the formulaic detective exposition with the introduction of the characters, the presentation of the crime, and the roster of suspects. The second part was entirely a flashback that reveals the history of the criminal himself which is quite a perplexing plot device and Doyle had definitely experimented the first time around but has since learned to contain his cases with more creative restraint. The Sign of Four, was about as close as to romance as a Holmes story could get, possibly because of Watson's relationship with his wife to be Mary Morstan and the struggles she faced pertaining to her heirloom. The next set of short stories, Adventures and Memoirs, are each composed of twelve cases and some of them are most unforgettable because of the blend of absurdity and horror, such as the Musgrave Ritual, Five Orange Pips, Red-Headed league, and Speckled Band.

The Final Problem marks the death of Sherlock Holmes which the public vehemently protested so Doyle was forced to revive his sleuth and hence the second volume of the canon, and in this volume I includes the early novel a study in scarlet, which introduced the eccentric genius of Sherlock Holmes to the world. This baffling murder mystery, with the cryptic word Rache written in blood, first brought Holmes together with Dr. John Watson. Next, the sign of four presents Holmes's famous, "Seven percent solution" and the strange puzzle of Mary Morstan in the quintessential locked room mystery. Also included are Holems's feats of extraordinary detection in such famous cases as the chilling "The adventure of the speckled band," the baffling riddle of "the Musgrave of the speckled band," the baffling riddle of "the Musgrave ritual," and the ingeniously plotted "the five orange pips," where Sherlock Holmes earned his undisputed reputation as the greatest fictional detective of all time. Volume 2 contains the ever popular The Hound of Baskervilles and the chilling novel A Valley of Fear. The short stories are divided into The Return, The Casebook and His Last Bow. The Problem of Thor Bridge, 
Devil's Foot, The Dying Detective, The Illustrious Client, and His Last Bow. Holmes himself got to write his own accounts of the cases in The Blanched Solider and The Lion's Mane. It is worth noting that when Holmes returned from the grave, Doyle has completely added more ambiguous layers to his personality and characterization which is why the second volume is the most enjoyable for its gray shades of morality and scope of justice and punishment. For instant gratification, the Granada series starring Jeremy Brett is the closest adaptation to the original source material.

\section{WHAT WE LEARN AS A LAW STUDENT FROM THE BOOK}

What we can learn as a law student from this book is Sherlock Holmes as a main character, is a genius with passion, perhaps obsession, with forensic puzzles. Sherlock Holmes was a wonderful novel. The villains, a woman who dumped him, a crazy freak with a nervous laugh, a terrifying gangleader named Moriarty. Only three of a plethora of villains also the plots, the mysteries, the three-dimensional characters, the excitement, the wisdom was all good.

Best quote in the entire novel is "'Lie number one,' said the old man; 'I never saw either of them until two months ago, and I have never been in Africa in my life, so you can put that in your pipe and smoke it, Mr. Busybody Holmes!"' this quote means that all of the mistake, lie always wrong, and why we should lie above it.

And the most surprising thing about the Sherlock Holmes body of work presented in this volume is that it does not consist primarily of detective stories or mystery novels. Rather, these tales are about, principally, Sherlock Holmes himself. They are a character study into one of the most eccentric, fascinating, and winsome persons to ever originate 
from the printed page. As masterful as Sherlock is at solving crimes and unravelling clues, even more genius is Conan Doyle's ability to present him in such a compelling, engaging way, story after story, circumstance after circumstance. By the end, some of the situations do repeat with variations on murders, missing persons, and various forms of burglary or swindling, there is surprisingly little "hard crime" or deep villainy in many of these tales. It's often the case that the problem stems from "Victorians acting badly", which is refreshing. And after reading this novel, we don't really need all that grit and salaciousness and gore, it turns out to be intrigued, especially not when we're following in the footsteps of someone as singular and fascinating as Holmes. The main draw here is simply sitting back and watching what the famous sleuth of 221 B Baker Street will do next. Holmes must stand with Jekyll and Hyde, Frankenstein, and Dracula, as one of the towering figures of nineteenth-century fiction.

And as we learn is, he (Sherlock Holmes) stands in the place of the reader as the perfect guide to the uncovering of the greatest mystery of all, just who Sherlock Holmes really is and what makes him tick. His reactions are just what the readers would be if we were in his place. Though he has no doubt puts it more eloquently than we would have. True crime buffs may be disappointed that they cannot connect all the dots as Sherlock Holmes does and often the revelations are presented in long confessions by the guilty are the end of a story. But if, they're missing the point, but the point here is Mr. Sherlock Holmes. It rights, the mysteries are puzzling and mind-boggling at times. We are not supposed to solve them, though, we were only there to cheer Holmes for another brilliant display of logic and inductive reasoning. We aren't him. We don't have his skills and that's fine. It is enough that we, like Watson get to spend so many pages simply basking in awe at this "brain without a heart." If Jekyll and Hyde are the result of the separation between the good and evil in one man, Holmes represents the complete divorce between two other aspects of our nature, that which thinks and that which feels. And in him, never the twain shall meet. Well, almost never, anyway. 


\section{Conflicting Interest Statement}

All authors declared that there is no potential conflict of interest on publishing this article.

\section{Funding}

None

\section{Publishing Ethical and Originality Statement}

All authors declared that this work is original and has never been published in any form and in any media, nor is it under consideration for publication in any journal, and all sources cited in this work refer to the basic standards of scientific citation. 